\section{ECCOMAS}

Proceedia
COMPDYN 2021

$8^{\text {th }}$ ECCOMAS Thematic Conference on Computational Methods in Structural Dynamics and Earthquake Engineering

M. Papadrakakis, M. Fragiadakis (eds.) Streamed from Athens, Greece, 28 - 30 June 2021

\title{
PRELIMINARY NUMERICAL ANALYSIS OF THE SEISMIC RESPONSE OF STEEL FRAMES WITH MASONRY INFILLS RETROFITTED BY BUCKLING RESTRAINED BRACES
}

\author{
Fernando Gutiérrez-Urzúa ${ }^{1}$, Fabio Freddi ${ }^{1}$, Luigi Di Sarno ${ }^{2}$, Jing-Ren Wu ${ }^{2}$, Mario \\ D'Aniello ${ }^{3}$, Raffaele Landolfo ${ }^{3}$, and Stathis Bousias ${ }^{4}$ \\ ${ }^{1}$ Dept. of Civil, Environmental \& Geomatic Engineering, University College London \\ Gower St., London, WC1E 6BT, U.K. \\ \{f.urzua,f.freddi\}@ucl.ac.uk \\ ${ }^{2}$ Dept. of Civil Eng. \& Industrial Design, University of Liverpool \\ Brownlow Hill, Liverpool, L69 3GH, U.K. \\ \{Luigi.Di-Sarno,Jingren.Wu\}@liverpool.ac.uk
${ }^{3}$ Dept. of Structures for Eng. \& Architecture, University of Naples Federico II
Corso Umberto I, Naples, 80134, Italy
\{mdaniel,raffaele.landolfo\}@unina.it \\ ${ }^{4}$ Structures Laboratory (STRULAB), Civil Eng. Dept., University of Patras \\ Rio Patras, Patras, 265 04, Greece \\ sbousias@upatras.gr
}

\begin{abstract}
Existing steel moment-resisting frames in several seismic regions worldwide are often characterised by high vulnerability to earthquakes due to insufficient local and/or global ductility. Nowadays, it is of paramount importance to assess their response under strong motions and provide cost-effective retrofitting strategies. Amongst others, the seismic behaviour of these frames is often strongly affected by the presence of masonry infills which, from one side, if adequately distributed, beneficially contribute to the seismic resistance of the structure providing stiffness and strength to the frame, from the other side often experience a brittle behaviour and are very vulnerable to seismic actions. To this end, the H2020-INFRAIA-SERA project HITFRAMES (i.e., HybrId Testing of an Existing Steel Frame with Infills under Multiple EarthquakeS) experimentally evaluated a case study building representative of non-seismically designed European steel frames with masonry infills and investigated a possible retrofit strategy. This paper takes advantage of the experimental results of the HITFRAMES project to calibrate numerical models in OpenSees of a case study building which is analysed as bare, infilled and retrofitted frame with buckling-restrained braces (BRBS). The impact of masonry infills and $B R B$-retrofit is investigated by comparing the response of models with different configurations.
\end{abstract}


The numerical results provide some insights on the ability of BRB-retrofit option in protecting not only the steel frames from experiencing critical damage during earthquakes but also the masonry infills and on the importance of using appropriate models for the masonry infills in the assessment procedures.

Keywords: Existing steel frames, Retrofitting, Buckling-restrained braces, Masonry infills, Seismic response, Numerical Simulations. 


\section{INTRODUCTION}

Many existing steel structures worldwide were built before the introduction of modern seismic design provisions and may exhibit high seismic vulnerability due to lack of proper lateral resisting systems and detailing, as well as inadequate energy dissipation capacity [1,2]. Among others, Di Sarno et al. [3] investigated the failure patterns of an existing steel moment resisting frames (MRFs) located in Amatrice and damaged by the 2016 Central Italy earthquakes. The case study structure was characterised by large residual lateral drifts with significant yielding at beam-column connections and soft storey mechanisms. Severe damage was also noted in non-structural components, including in-plane and out-of-plane failure of masonry infill walls. This damage is consistent with damage reported in previous earthquakes (e.g., [4-6]). Although masonry infills can significantly contribute to the overall strength and stiffness of a steel MRF [7-9], their structural properties easily degrade with strong or long ground motions (GMs), as well as with cumulative demands, such as foreshock-mainshock-aftershock sequences, as in the case of the 2016 Central Italy Earthquake [10-13].

In this context, the H2020-SERA project HITFRAMES (Hybrid Testing of an Existing Steel Frame with Infills under Multiple Earthquakes) is aimed on assessing the seismic performance of existing steel frames with masonry infills under multiple earthquakes and the feasibility of retrofitting with buckling restrained braces (BRBs) [14-18]. Among others, the objectives of the HITFRAMES project include: (1) to experimentally assess the seismic performance of nonseismically designed steel frames with masonry infills under earthquake sequences, including the effects of cumulative damage; (2) to evaluate the existing masonry infill models and to develop new calibrated models aimed at describing the behaviour of masonry panels within infilled steel MRFs; and (3) to experimentally evaluate the contribution and effectiveness of BRB-based retrofitting strategies in steel MRFs.

Figure 1 shows the set-up of the experimental test carried out as part of the HITFRAMES project. It consists of a 75\% scaled, two-storey steel MRF, designed primarily for gravity loads with insufficient seismic detailing [19,20]. The test was conducted at the Structures Laboratory (STRULAB) of the University of Patras, Greece, and it included a pseudo-dynamic (PsD) testing procedure. The prototype building was designed to be a representative of non-seismically designed steel frames based on the characteristics observed in the Amatrice building [3]. The specimen was subjected to GM sequences, based on GMs recorded at Norcia (NRC) station, in Central Italy, and summarised in Table 1.

The present paper proposes a preliminary numerical study of the seismic response of the steel building tested during the HITFRAMES experimental campaign. First, a preliminary calibrated masonry strut model is developed, based on the observations of the HITFRAMES experiment. This model is compared with three widely used single strut masonry models available in literature, through time history analysis and by considering GM1. Then, the numerical model is retrofitted by means of BRBs, in order to evaluate the effectiveness of the devices when interacting with the masonry panels. Finally, conclusions are drawn highlighting the relevance of accurately modelling the masonry infills while assessing the performance of the retrofitted structure.

\begin{tabular}{lllll}
\hline Event & Date \& time & Mw & $R_{\text {epi }}[\mathrm{km}]$ & PGA [ g ] \\
\hline GM1 & $24 / 08 / 20161: 36$ & 6.0 & 15.3 & 0.35 \\
GM2 & $30 / 10 / 20166: 40$ & 6.5 & 4.6 & 0.48 \\
GM3 & 26/10/2016 17:10 & 5.4 & 9.4 & 0.3 \\
\hline
\end{tabular}

Table 1: Main characteristics of the GMs used during the HITFRAMES experimental campaign. 


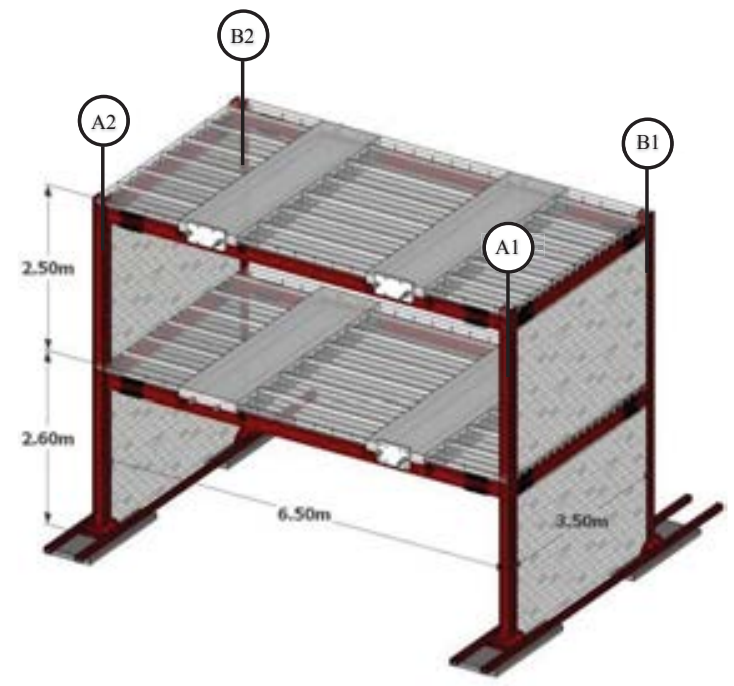

(a)

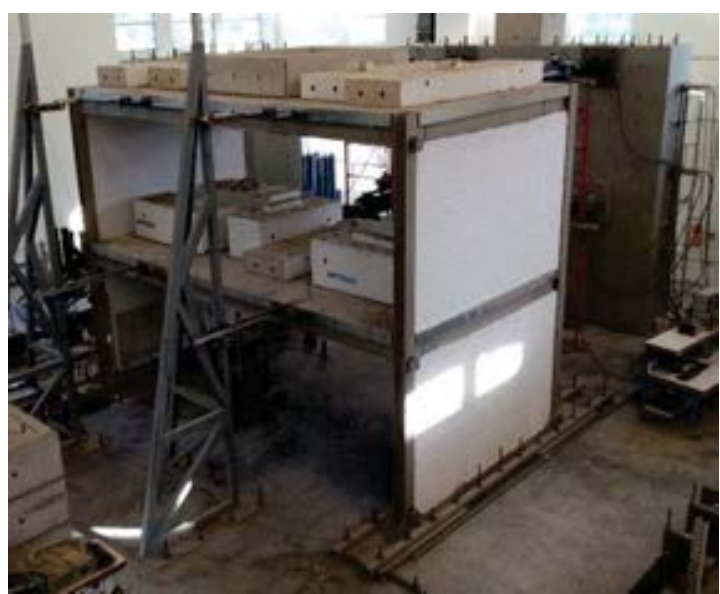

(b)

Figure 1: Experiment set-up: (a) 3D model of lab specimen; (b) constructed lab specimen.

\section{EVALUATION OF EXISTING MASONRY INFILL MODELS}

For the present paper, a non-linear OpenSees numerical model [21] is developed. Columns are modelled with a distributed plasticity approach (Steel01), while the beams are modelled by considering a lumped plasticity approach. In the latter approach, plastic hinges are modelled by considering the formulation by Lignos and Krawinkler [22] and modified according to Zareian and Medina [23]. Material properties are consistent with the characterisation tests performed on the steel members after the experiments.

Masonry panels are included by considering a macro-modelling approach, which consists of one simple compression-only diagonal strut on each direction (i.e. in X shape). The behaviour of the masonry infills is represented by using a pinching 4 OpenSees material.

\subsection{Calibration of masonry infill struts based on experimental results}

The calibration of masonry struts is carried out by reproducing the deformation history imposed during the PsD testing in an OpenSees numerical model. The full GM sequence comprises six records in the following order: GM1, GM1, GM2, GM3, GM1 and GM2, with the last two upscaled to $300 \%$ in the acceleration axis. As the $75 \%$ scaling rules followed for the lab specimen consider constant stress, the time axis in the accelerogram is also multiplied by $0.75^{1 / 2}=0.87$ in all GMs.

The masonry strut displacement values $\left(\delta_{\mathrm{n}}\right)$ are directly obtained from the horizontal floor deformation $\left(\Delta_{n}\right)$, assuming negligible vertical deformation and by considering a simple geometric transformation, as follows

$$
\delta_{\mathrm{n}}=\mathrm{d}_{\mathrm{n}}-\mathrm{d}_{0}=\sqrt{\mathrm{d}_{0}^{2}+2 \mathrm{~L} \Delta_{\mathrm{n}}+\Delta_{\mathrm{n}}^{2}}-\mathrm{d}_{0}
$$

where $\mathrm{d}_{0}$ is the undeformed diagonal length, $\mathrm{d}_{\mathrm{n}}$ is the deformed diagonal length at step $\mathrm{n}$, and $\mathrm{L}$ is the span length of the frame. Forces are estimated under the assumption that the MRF system works in parallel with the masonry strut, which effectively creates a truss-like mechanism with the steel frame (i.e., the infill-frame interaction does not modify the frame deformation pattern), therefore, the forces assigned to the masonry strut in the numerical model are simply a subtraction of the total storey shear minus the storey shear exhibited by the bare frame at the same level of storey drift. 
For this purpose, the elastic and modal properties of the bare frame OpenSees model are validated by comparing the results of the lab characterisation tests (i.e., material testing, snapback test) [13] with the numerical model. The validated numerical model of the bare frame is then subjected to the storey displacement history observed during the PsD testing in a displacement-controlled manner, with the resulting storey shear values $\left(\mathrm{V}_{\mathrm{n}}\right)$ recorded. The resulting horizontal shear values at each storey $\left(\mathrm{V}_{\mathrm{n}}\right)$ are approximated to diagonal equivalent forces $\left(\mathrm{F}_{\mathrm{n}}\right)$, as follows

$$
\mathrm{F}_{\mathrm{n}}=\frac{\mathrm{V}_{\mathrm{n}} \sqrt{\mathrm{h}^{2}+\left(\Delta_{\mathrm{n}}+\mathrm{L}\right)^{2}}}{\Delta_{\mathrm{n}}+\mathrm{L}}
$$

where $\mathrm{h}$ is the inter storey height.

Figure 2 shows the forces and deformations attributed to one masonry panel (i.e., one compression-only strut on each direction) in comparison with the calibrated model. Four masonry panels per storey are considered in the numerical model (i.e., two double layer walls), therefore, the struts shown in Figure 2 only withstand one quarter of the total load. The masonry struts are calibrated on the pinching4 material in OpenSees, and their properties are summarised in Table 2 .
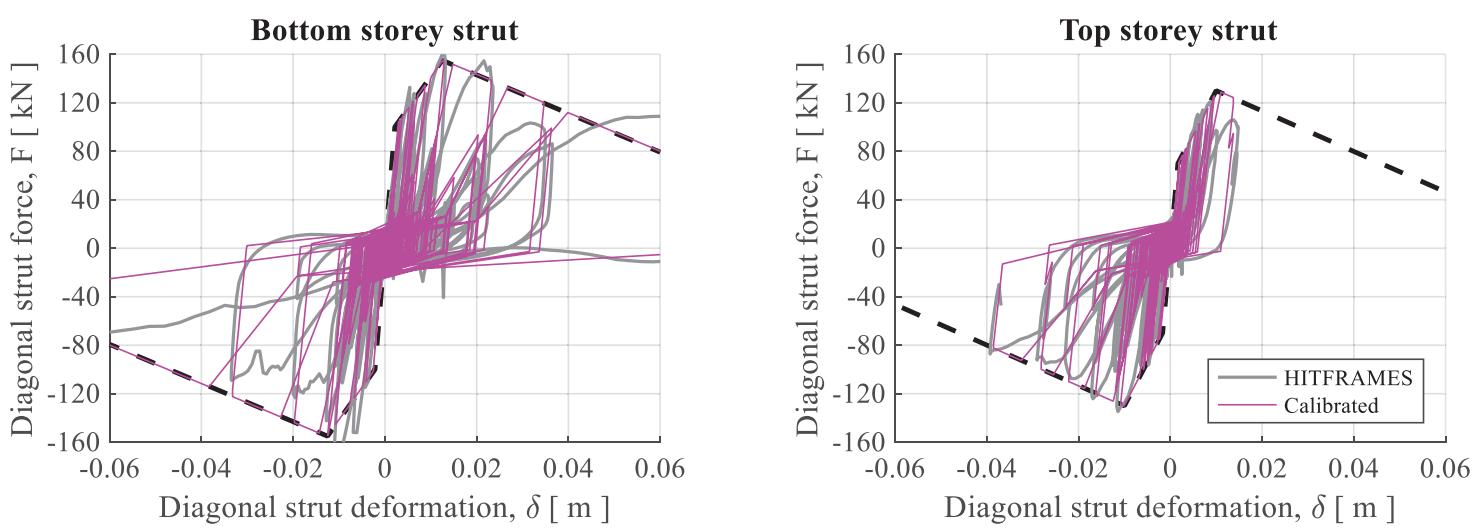

Figure 2: Hysteretic behaviour of the masonry struts during the HITFRAMES experiments, in comparison with the calibrated model. The calibrated pinching parameters are $\mathrm{rDisp}=0.5, \mathrm{rForce}=0.2$, $\mathrm{uForce}=0.05$. The calibrated degradation parameters are $\mathrm{gK} 1=0.15, \mathrm{gD} 1=0.15$, while all the others keep their default values.

\subsection{Comparison of existing masonry infill models with experimental results}

Several masonry strut models have been proposed in literature, nonetheless, most of them have been calibrated for reinforced concrete (RC) frames and their application to steel frames is not yet validated. Some of these models comprise complex strut configurations (e.g., multiple struts, additional shear springs, etc.), nonetheless, the most common ones are based on a single strut approach.

Panagiotakos and Fardis (PF) $[7,24]$ proposed a single-strut constitutive model to represent the behaviour of solid (i.e., with no openings) masonry infills in RC frames. This model is characterised by four stress states: (1) initial elastic behaviour of the uncracked masonry infill; (2) post-elastic linear response, characterised by a reduced stiffness; (3) softening of the masonry panel after the maximum force; and, (4) residual axial strength region. The strut resistance is calculated based on the area of the masonry strut, which is the product of the wall thickness and the theoretical width of the strut. This measure depends not only on the properties of the masonry wall, but also on the surrounding frame. Dolšek and Fajfar (DF) [8] proposed a similar model whose main difference is to have a strut resistance implicitly calculated in the capacity formulations. In addition, this model considers that the masonry strut possesses no residual capacity. Decanini and Fantin [25] proposed a model, successively updated by Liberatore and 
Decanini (LD) [26], for the evaluation of the seismic response of high-rise RC buildings designed as bare frames but with significant infill contribution. This model considers empirical relationships to define the horizontal capacity and stiffness of the struts.

A comparison of the calibrated masonry strut model is made with the aforementioned models proposed in literature and is shown in Figure 3. The basic material properties of the masonry were obtained from material characterisation tests: compressive strength, $\sigma_{\mathrm{w} 0}=2.85 \mathrm{MPa}$; shear strength, $\tau_{\mathrm{w} 0}=0.653 \mathrm{MPa}$. The elastic modulus was estimated by using the relationship proposed by FEMA 356 [27], $\mathrm{E}_{\mathrm{w} 0}=550 \sigma_{\mathrm{w} 0}$, while the shear modulus is considered to be $\mathrm{G}_{\mathrm{w} 0}=$ $0.4 \mathrm{E}_{\mathrm{w} 0}$. The following observations can be made from the comparison with the calibrated masonry struts: (1) the calibrated model for the bottom storey seems to have more similarities in terms of forces with the PF model and the DF model; (2) the LD model tends to underestimate the force capacity and to overestimate the deformation capacity; regardless of the similar interstorey heights, the top masonry strut exhibits lower capacity; and (4) the calibrated model exhibits lower initial and post-yielding stiffness than any of the models available in literature. A comparison of the backbone properties for each model is detailed in Table 2.

Figure 4 shows a comparison of the storey shear response obtained during the GM1 of the displacement-based test, by considering the LD and the calibrated models. As observed, the LD shows larger force at low values of displacement, in comparison with the calibrated model. On the other hand, forces are larger in the calibrated model at large displacement values. These observations are consistent with the larger initial stiffness and lower maximum force capacity of the LD model.

\begin{tabular}{|c|c|c|c|c|c|}
\hline Storey & $\begin{array}{l}\text { Properties } \\
{[\mathrm{kN}, \mathrm{m}]}\end{array}$ & Calibrated & PF & DF & LD \\
\hline \multirow[t]{9}{*}{1} & $\mathrm{~F}_{\mathrm{y}}(\mathrm{eNf1})$ & -100 & -132.6 & -88.9 & -75.5 \\
\hline & $\mathrm{F}_{\mathrm{m}}(\mathrm{eNf} 2)$ & -155 & -172.3 & -148.2 & -94.4 \\
\hline & $\mathrm{F}_{\mathrm{u}}(\mathrm{eNf3})$ & -15.5 & -13.3 & 0 & -32.6 \\
\hline & $\mathrm{k}_{1}$ & 45455 & 60273 & 59267 & 94375 \\
\hline & $\mathrm{k}_{2}$ & 5340 & 14704 & 21179 & 4974 \\
\hline & $\mathrm{k}_{3}$ & -1594 & -2972 & -2976 & -415 \\
\hline & $\delta_{\mathrm{y}}(\mathrm{eNd} 1)$ & -0.0022 & -0.0022 & -0.0015 & -0.0008 \\
\hline & $\delta_{\mathrm{m}}(\mathrm{eNd} 2)$ & -0.0125 & -0.0049 & -0.0043 & -0.0046 \\
\hline & $\delta_{\mathrm{u}}(\mathrm{eNd} 3)$ & -0.1 & -0.0584 & -0.0541 & -0.1535 \\
\hline \multirow[t]{9}{*}{2} & $\mathrm{~F}_{\mathrm{y}}(\mathrm{eNf1})$ & -70 & -132.6 & -88.9 & -78.2 \\
\hline & $\mathrm{F}_{\mathrm{m}}(\mathrm{eNf} 2)$ & -130 & -172.3 & -148.2 & -97.7 \\
\hline & $\mathrm{F}_{\mathrm{u}}(\mathrm{eNf3})$ & -13 & -13.3 & 0 & -33.6 \\
\hline & $\mathrm{k}_{1}$ & 41176 & 60273 & 59267 & 86889 \\
\hline & $\mathrm{k}_{2}$ & 7229 & 14704 & 21179 & 4875 \\
\hline & $\mathrm{k}_{3}$ & -1671 & -2972 & -2976 & -400 \\
\hline & $\delta_{\mathrm{y}}(\mathrm{eNd} 1)$ & -0.0017 & -0.0022 & -0.0015 & -0.0009 \\
\hline & $\delta_{\mathrm{m}}(\mathrm{eNd} 2)$ & -0.01 & -0.0049 & -0.0043 & -0.0049 \\
\hline & $\delta_{\mathrm{u}}(\mathrm{eNd} 3)$ & -0.08 & -0.0584 & -0.0541 & -0.1653 \\
\hline
\end{tabular}

Table 2: Comparison among the parameters of the masonry strut calibrated model and the models of Panagiotakos and Fardis (PF) [7,24], Dolšek and Fajfar (DF) [8] and Liberatore and Decanini (LD) [26]. 


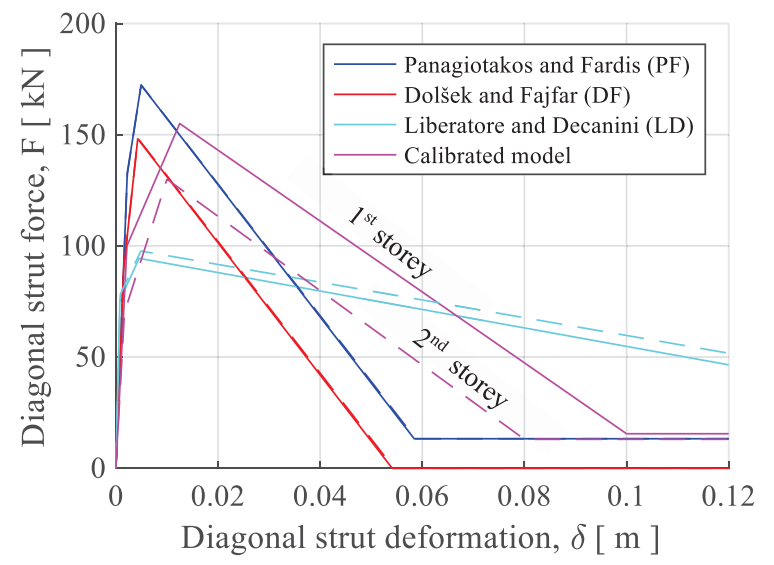

Figure 3. Comparison among the force-displacement curves of the masonry strut calibrated model and the models of Panagiotakos and Fardis (PF) [7,24], Dolšek and Fajfar (DF) [8] and Liberatore and Decanini (LD) [26].

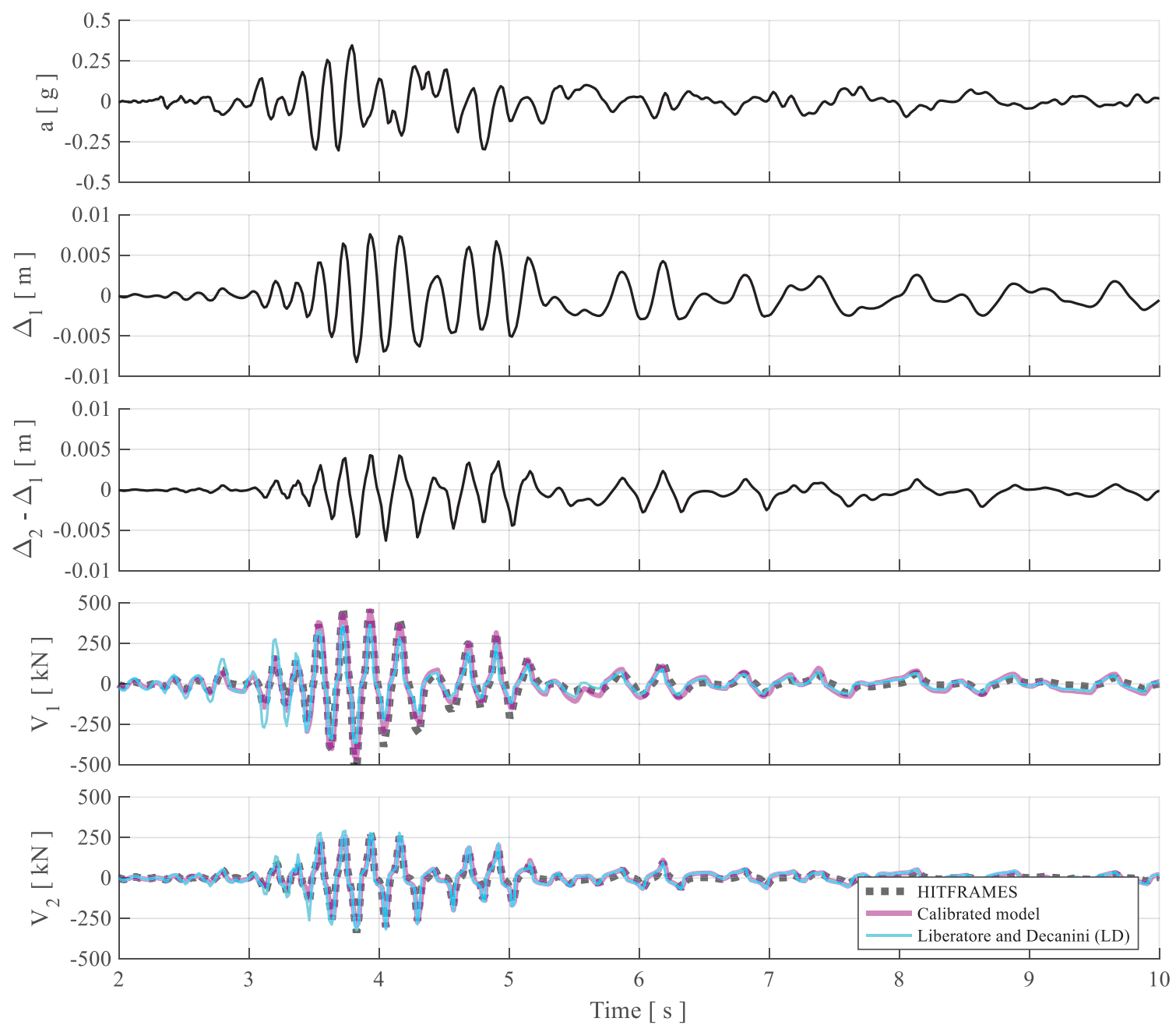

Figure 4. Storey shear output during GM1, considering the frame with the masonry strut calibrated model and the Liberatore and Decanini (LD) [26] model subjected to a displacement-controlled test. 


\section{ASSESSMENT OF THE RETROFITTED STRUCTURE}

The frame with calibrated masonry struts is retrofitted by including diagonal steel braces equipped with BRBs. The sizing of the device is carried out by a simplified code-based design approach. For this matter, the structure is considered to be located in Central Italy and the design of the retrofitting was done in accordance with the recommendations of the Eurocode 8 Part 1 (EC8-1) [28] and Eurocode 3 Part 1-1 (EC3-1-1) [29]. The design is performed for the Ultimate Limit State (i.e., probability of exceedance of $10 \%$ in 50 years), considering a Type 1 spectrum, with soil Type B, and Peak Ground Acceleration (PGA) equal to $0.25 \mathrm{~g}$. The structure is designed by considering a basic behaviour factor $\mathrm{q}_{0}=3$. The design requirements are paired with a commercial catalogue of BRB devices, and result on a device with an initial yielding force $\mathrm{F}_{\mathrm{y} 0-\mathrm{BRB}}=143 \mathrm{kN}$. The device is included in the numerical model by using the SteelBRB model [30] in OpenSees. The monotonic and hysteretic properties of the device are validated with a characterisation test made by the manufacturer. The hysteretic behaviour of the BRB model is shown in Figure 5. The length of the BRB is $1.535 \mathrm{~m}$, therefore, the device is connected in series to a steel tubular section $(\varnothing=0.16 \mathrm{~m}, \mathrm{t}=0.01 \mathrm{~m})$ which completes the diagonal length. The full $\mathrm{BRB}$ and elastic brace system is pinned at the ends.

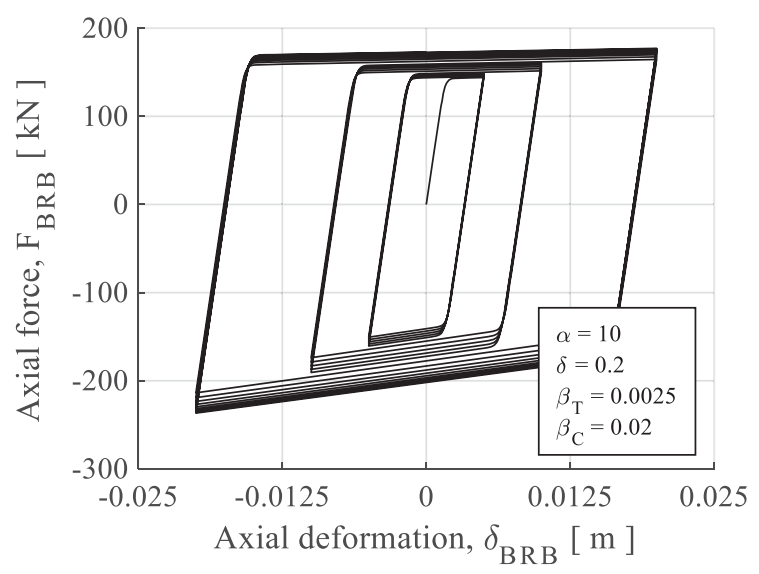

Figure 5. BRB model in OpenSees by using the SteelBRB material. $\mathrm{F}_{\mathrm{y} 0 \text {-BRB }}=143 \mathrm{kN} ; \mathrm{F}_{1-\mathrm{BRB}-\mathrm{C}}=178 \mathrm{kN}$; $\mathrm{F}_{1-\mathrm{BRB}-\mathrm{T}}$ $=151 \mathrm{kN}$.

Time history analyses based on GM1 were performed on the unretrofitted and retrofitted structures, by considering the calibrated masonry strut model and the LD model. Figure 6 shows the spectrum of GM1 and the comparison of the spectral accelerations $\left(\mathrm{S}_{\mathrm{a}}\right)$ corresponding to the fundamental period of each structure. The period of the unretrofitted calibrated structure matches the observed fundamental period during the characterisation test of the lab specimen. The addition of the BRBs further reduces its fundamental period to $0.11 \mathrm{~s}$. While considering the LD model, the fundamental period is shorter in the unretrofitted structure due to the higher initial stiffness of the struts and reaches a value of $0.09 \mathrm{~s}$ with the addition of BRBs. As observed in Figure 6, for the considered GM, the retrofitted structures benefit from a slight reduction on the demand due to the increased stiffness.

Figure 7, Figure 8, Figure 9 show the inter-storey deformation and storey shear demands during the time history analysis of GM1, for the calibrated and LD masonry strut models, considering the unretrofitted and retrofitted conditions. The deformation in the struts is compared with their own cracking deformation $\left(\delta_{\mathrm{y}}\right)$, as suggested by the ASCE 41-17 [31] as a limit for the Immediate Occupancy Performance Level. When comparing the unretrofitted cases, the LD model exhibits lower deformation and force values than the calibrated model, as it avoids the strut deformation to reach significant levels of cracking. Nonetheless, the calibrated model (as 
well as the lab specimen during the testing) exhibited extensive cracking in the struts. When comparing the retrofitted models, the addition of BRBs significantly reduce the demands on the masonry infills of the calibrated model. Nonetheless, the improvement is not as noticeable in the case of the LD model.

These observations highlight the sensitivity of considering higher values of initial stiffness in the masonry strut model. On one side, the larger stiffness underestimates the damage that the masonry panel could experience in the unretrofitted case. On the other side, it underestimates the capacity of the BRBs in protecting the masonry infills from damage in moderate intensity earthquakes.

Therefore, when the masonry strut properties are properly accounted for, the BRBs can protect the case-study structure from damage at lower and moderate intensity earthquakes, while they simultaneously increase the energy dissipation capacity of the structure at higher levels of demands.
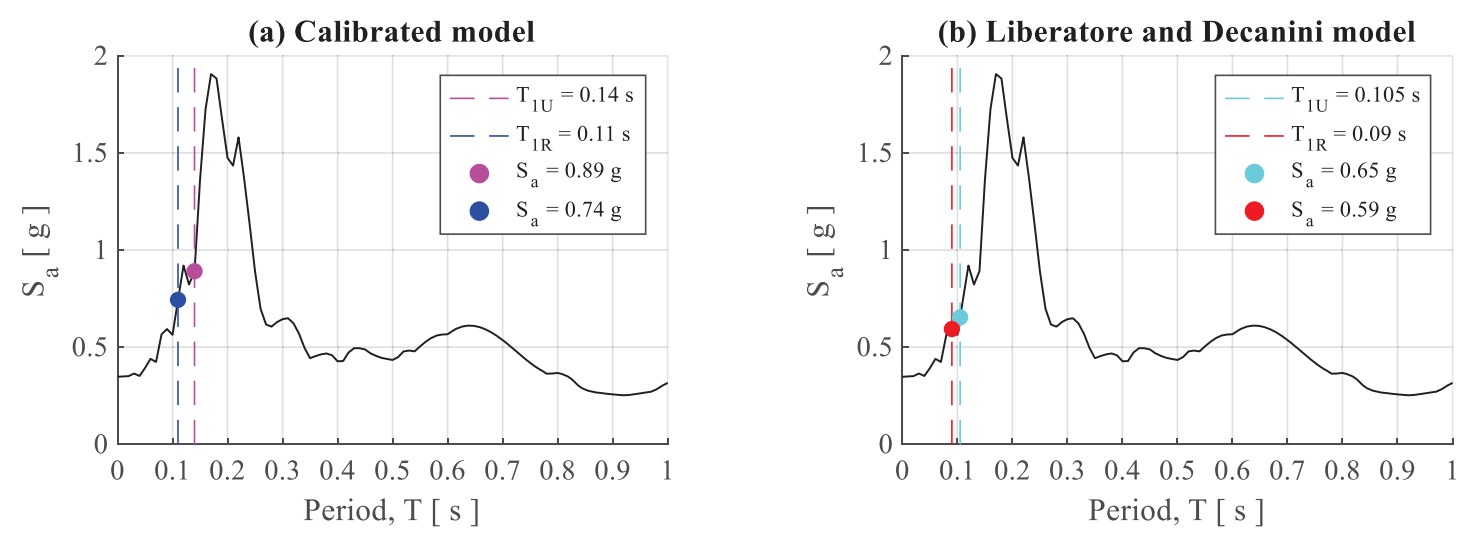

Figure 6. Response spectrum for GM1, considering 3.3\% damping, along with the fundamental period of the infilled frame model considering (a) the calibrated strut model and (b) the Liberatore and Decanini strut model [26].
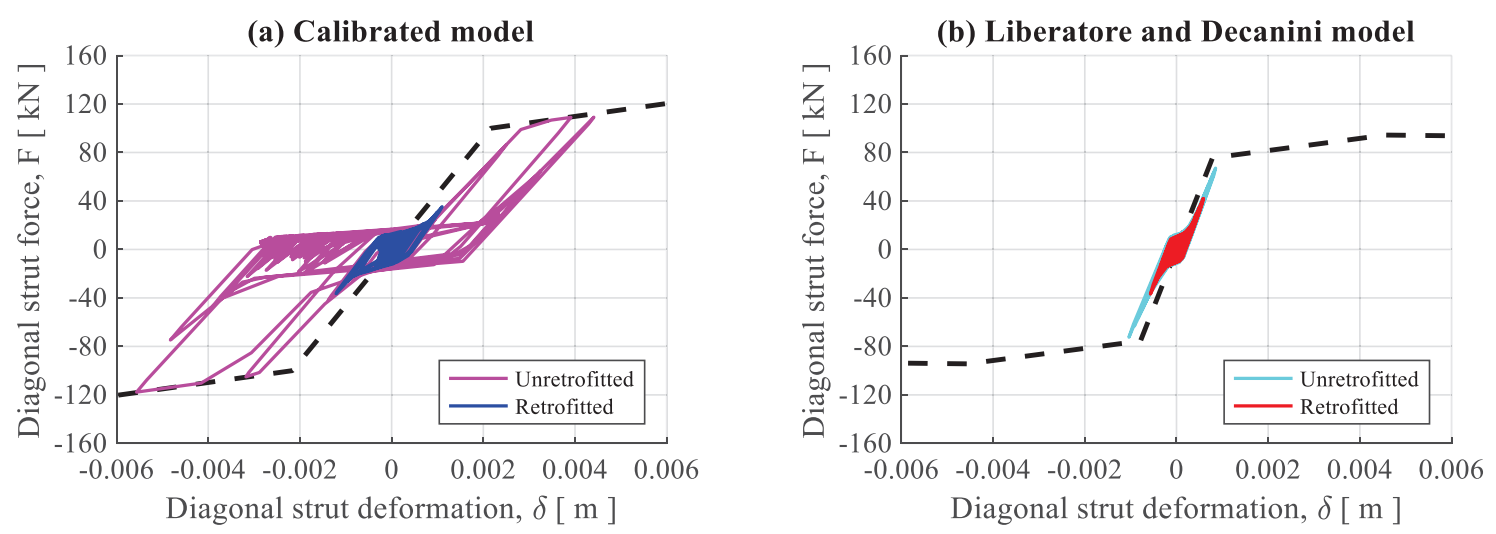

Figure 7. Hysteretic behaviour of masonry struts in the first storey during GM1 considering the (a) calibrated strut model and (b) Liberatore and Decanini strut model [26]. 


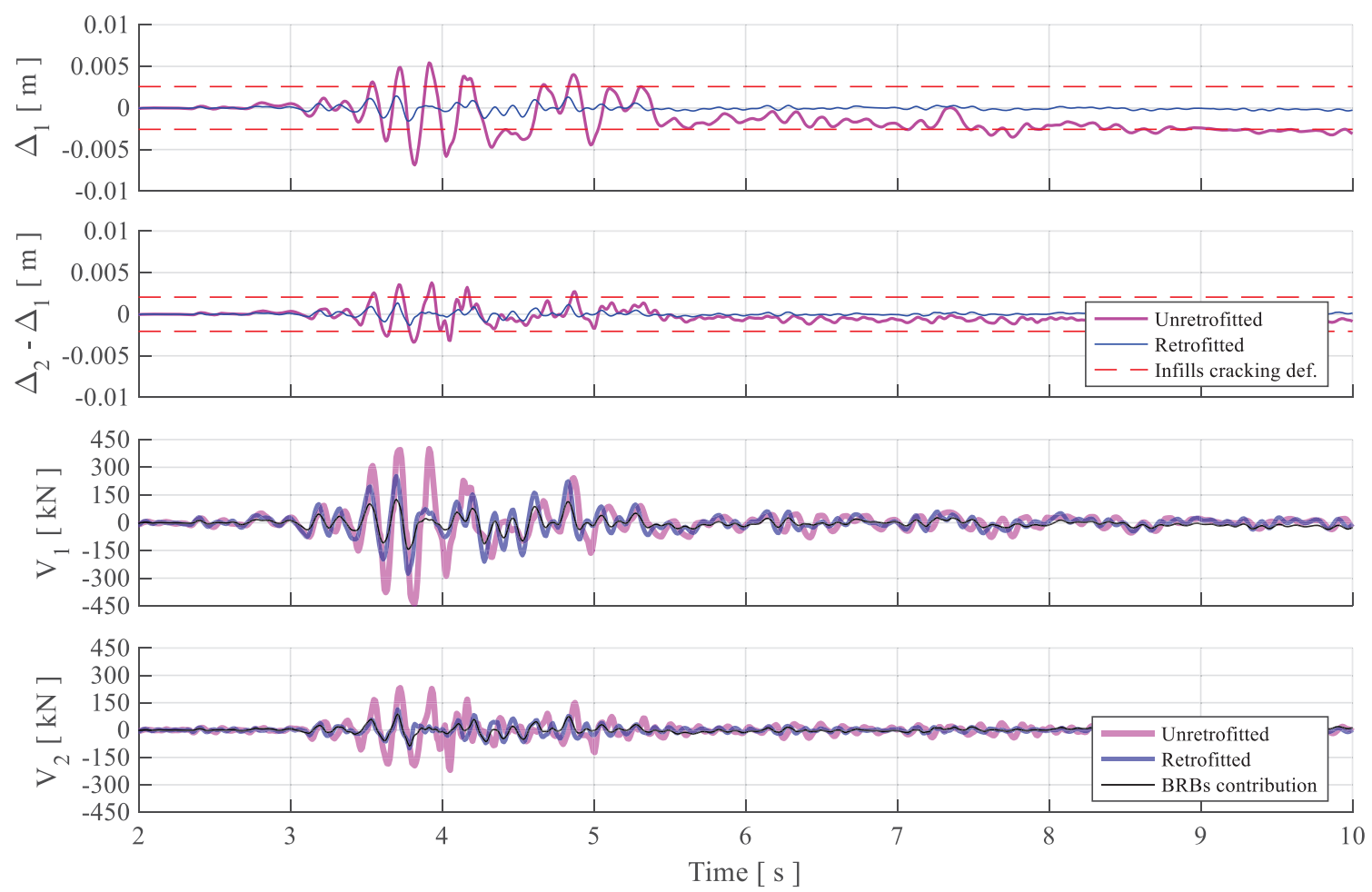

Figure 8. Inter-storey drift and storey shear comparison between the unretrofitted and retrofitted structures when considering the calibrated model for masonry struts.

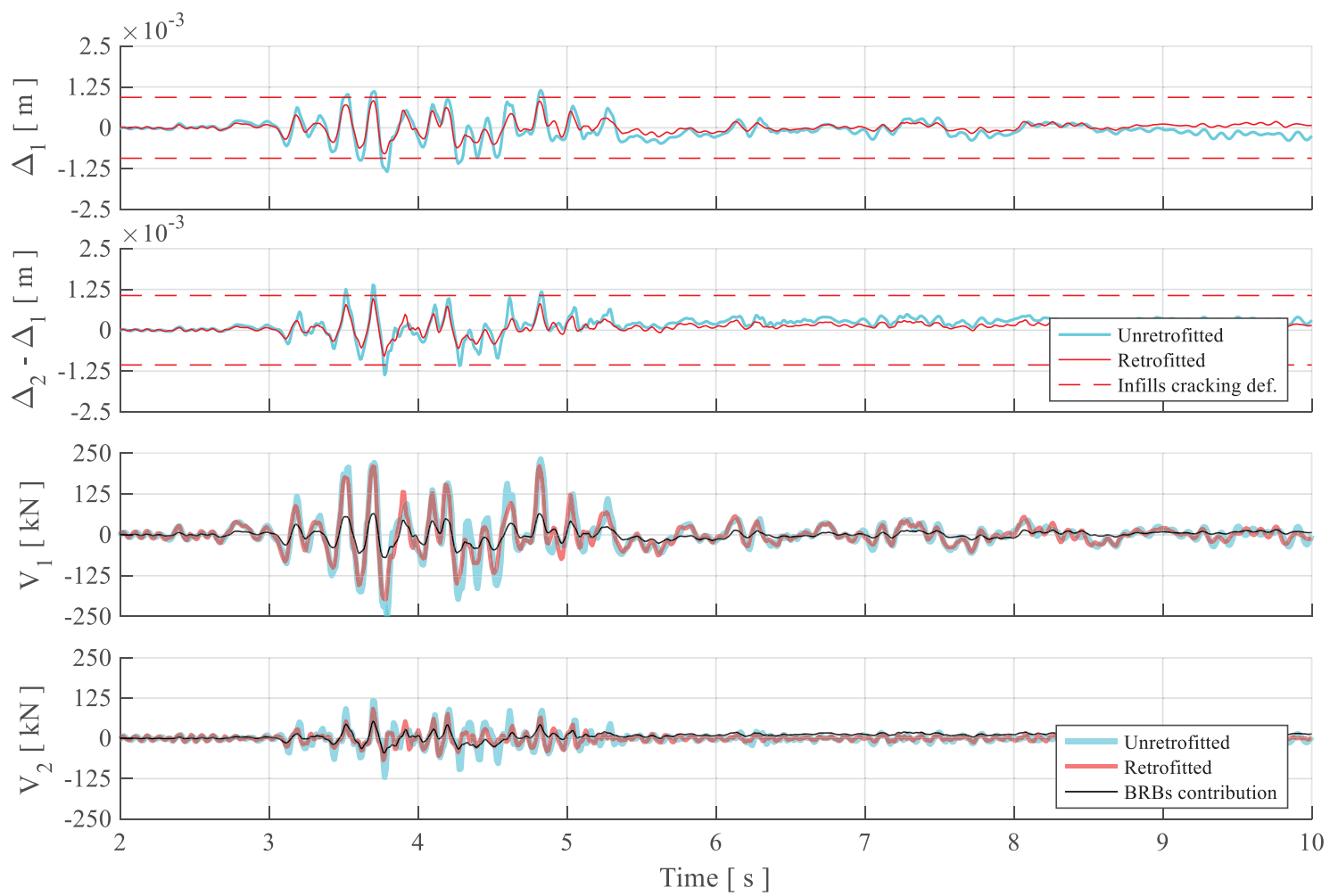

Figure 9. Inter-storey drift and storey shear comparison between the unretrofitted and retrofitted structures when considering the Liberatore and Decanini [26] model for masonry struts. 


\section{CONCLUSIONS}

The present paper investigates the interaction of masonry infills and buckling restrained braces (BRBs) when these are used as a retrofit measure in existing steel moment resisting frames (MRFs). The study takes advantage of the experimental results of the HITFRAMES project to calibrate numerical models in OpenSees for a case study steel MRF which has been analysed as bare, infilled and retrofitted frame with BRBs. The impact of masonry infills and BRB-retrofit is investigated by comparing the response of different infills models. The numerical results provide some insights on the ability of BRB-retrofit option in protecting not only the steel frames from experiencing critical damage during earthquakes but also the masonry infills and on the importance of using appropriate modelling strategies for the masonry infills during the assessment procedures. The following conclusions can be drawn:

- All of the considered masonry strut models exhibited larger values of initial stiffness, in comparison with the calibrated model. The Panagiotakos and Fardis (PF) model, and the Dolšek and Fajfar (DF) model, exhibited larger force capacity but lower deformation capacity than the calibrated model. The Liberatore and Decanini (LD) model exhibited lower force capacity but higher deformation capacity than the calibrated model.

- Large values of initial stiffness were translated in an underestimation of the seismic demands (for GM1) and an overestimation of the capacity. This could lead to larger than expected levels of damage in masonry panels. The calibrated model is able to capture the cracking observed during GM1 in the pseudo-dynamic testing carried out on the lab specimen.

- The addition of BRBs as a retrofit measure for masonry infilled steel MRFs can reduce the damage in the masonry infills at low and moderate seismic demands. Nonetheless, it is necessary to consider a more accurate masonry strut model in the numerical analysis, as the relative stiffness between the masonry and BRB system will dictate the capacity of the BRB to protect the infills.

\section{ACKNOWLEDGEMENTS}

The financial support of the Seismic Engineering Research Infrastructure (SERA) project (European Commission, H2020-INFRAIA-2016-2017, Agreement No.730900) to HITFRAMES project is greatly acknowledged. FGU acknowledges the partial funding provided by partially funded by CONACYT-FiiDEM (Grant No. 2018-000013-01EXTF-00148). Any opinions, findings and conclusions, or recommendations expressed in this paper are those of the Authors and do not necessarily reflect those of the sponsors.

\section{REFERENCES}

[1] Federal Emergency Management Agency, State of the Art Report on Past Performance of Steel Moment-Frame Buildings in Earthquakes, FEMA 355E. (2000).

[2] F. Freddi, V. Novelli, R. Gentile, E. Veliu, S. Andreev, A. Andonov, F. Greco, E. Zhuleku, Observations from the 26th November 2019 Albania earthquake: the earthquake engineering field investigation team (EEFIT) mission, Bull. Earthq. Eng. 19 (2021) 2013-2044. https://doi.org/10.1007/s10518-021-01062-8.

[3] L. Di Sarno, F. Paolacci, A.G. Sextos, Seismic performance assessment of existing steel buildings: A case study, Key Eng. Mater. 763 (2018) 1067-1076. https://doi.org/10.4028/www.scientific.net/KEM.763.1067.

[4] S.A. Mahin, Lessons from damage to steel buildings during the Northridge earthquake, 
Eng. Struct. 20 (1998) 261-270. https://doi.org/10.1016/S0141-0296(97)00032-1.

[5] R. Tremblay, P. Timler, M. Bruneau, A. Filiatrault, Performance of lifelines during the 1994 Northridge earthquake, Can. J. Civ. Eng. 22 (1995) 338-360.

https://doi.org/10.1139/195-052.

[6] T. Okazaki, D.G. Lignos, M. Midorikawa, J.M. Ricles, J. Love, Damage to steel buildings observed after the 2011 Tohoku-oki earthquake, Earthq. Spectra. 29 (2013) 219-243. https://doi.org/10.1193/1.4000124.

[7] T.B. Panagiotakos, M.N. Fardis, Seismic response of infilled RC frame structures, in: 11th World Conf. Earthq. Eng., Acapulco, Mexico, 1996.

[8] M. Dolšek, P. Fajfar, The effect of masonry infills on the seismic response of a four storey reinforced concrete frame-a probabilistic assessment, Eng. Struct. 30 (2008) 3186-3192. https://doi.org/10.1016/j.engstruct.2008.04.031.

[9] M. Mohammadi, S.M. Motovali Emami, Multi-bay and pinned connection steel infilled frames; an experimental and numerical study, Eng. Struct. 188 (2019) 43-59. https://doi.org/10.1016/j.engstruct.2019.03.028.

[10] L. Di Sarno, J.R. Wu, Seismic assessment of existing steel frames with masonry infills, J. Constr. Steel Res. 169 (2020) 106040. https://doi.org/10.1016/j.jcsr.2020.106040.

[11] K. Aljawhari, R. Gentile, F. Freddi, C. Galasso, Effects of ground-motion sequences on fragility and vulnerability of case-study reinforced concrete frames, Bull. Earthq. Eng. (2020). https://doi.org/10.1007/s10518-020-01006-8.

[12] L. Di Sarno, J.R. Wu, Fragility assessment of existing low-rise steel moment-resisting frames with masonry infills under mainshock-aftershock earthquake sequences, Bull. Earthq. Eng. 19 (2021) 2483-2504. https://doi.org/10.1007/s10518-021-01080-6.

[13] L. Di Sarno, J.R. Wu, F. Gutiérrez-Urzúa, F. Freddi, M. D’Aniello, O.S. Kwon, S. Bousias, M. Dolšek, Dynamic response of existing steel frames with masonry infills under multiple earthquakes, Proc. Int. Conf. Struct. Dyn. , EURODYN. 2 (2020) 36713685. https://doi.org/10.47964/1120.9301.19738.

[14] L. Di Sarno, G. Manfredi, Seismic retrofitting with buckling restrained braces: Application to an existing non-ductile RC framed building, Soil Dyn. Earthq. Eng. 30 (2010) 1279-1297. https://doi.org/10.1016/j.soildyn.2010.06.001.

[15] G. Della Corte, M. D’Aniello, R. Landolfo, Field Testing of All-Steel BucklingRestrained Braces Applied to a Damaged Reinforced Concrete Building, J. Struct. Eng. 141 (2015) 1-11. https://doi.org/10.1061/(asce)st.1943-541x.0001080.

[16] F. Freddi, E. Tubaldi, A. Zona, A. Dall'Asta, Seismic performance of dual systems coupling moment-resisting and buckling-restrained braced frames, Earthq. Eng. Struct. Dyn. 50 (2021) 329-353. https://doi.org/10.1002/eqe.3332.

[17] F. Freddi, J. Ghosh, N. Kotoky, M. Raghunandan, Device uncertainty propagation in low-ductility RC frames retrofitted with BRBs for seismic risk mitigation, Earthq. Eng. Struct. Dyn. (2021) eqe.3456. https://doi.org/10.1002/eqe.3456.

[18] P. Castaldo, E. Tubaldi, F. Selvi, L. Gioiella, Seismic performance of an existing RC structure retrofitted with buckling restrained braces, J. Build. Eng. 33 (2021) 101688. https://doi.org/10.1016/j.jobe.2020.101688. 
[19] L. Di Sarno, J.R. Wu, M. D’Aniello, S. Costanzo, R. Landolfo, O.S. Kwon, F. Freddi, Assessment of existing steel frames with infills under multiple earthquakes, COMPDYN Proc. 3 (2019) 5813-5824. https://doi.org/10.7712/120119.7347.19837.

[20] F. Gutiérrez-Urzúa, F. Freddi, L. Di Sarno, Comparative analysis of code-based approaches for seismic assessment of existing steel moment resisting frames, J. Constr. Steel Res. 181 (2021) 106589. https://doi.org/10.1016/j.jcsr.2021.106589.

[21] F. McKenna, G.L. Fenves, M.H. Scott, Open system for earthquake engineering simulation (OpenSees), (2000).

[22] D.G. Lignos, H. Krawinkler, Deterioration modeling of steel components in support of collapse prediction of steel moment frames under earthquake loading, J. Struct. Eng. 137 (2011) 1291-1302. https://doi.org/10.1061/(ASCE)ST.1943-541X.0000376.

[23] F. Zareian, R.A. Medina, A practical method for proper modeling of structural damping in inelastic plane structural systems, Comput. Struct. 88 (2010) 45-53. https://doi.org/10.1016/j.compstruc.2009.08.001.

[24] T.B. Panagiotakos, M.N. Fardis, Proposed nonlinear strut model for infill panels, 1st Year Prog. Rep. HCM-PREC8 Proj. Univ. Patras. (1994).

[25] L.D. Decanini, G. Fantin, Modelos simplificados de la mampostería incluida en porticos. Características de resistencia en el estado límite., in: VI Jornadas Argentinas Ing. Estructural, Buenos Aires, Argentina., 1986.

[26] L. Liberatore, L.D. Decanini, Effect of infills on the seismic response of high-rise RC buildings designed as bare according to Eurocode 8, Ing. Sismica. 28 (2011) 7-23. http://www.scopus.com/inward/record.url?eid=2-s2.084859059861\&partnerID=40\&md5=5eab990ef5b233a5d5a7477c382flea9.

[27] Federal Emergency Management Agency, Prestandard and Commentary for the Seismic Rehabilitation of Buildings, FEMA 356. (2000).

[28] European Committee for Standardization (CEN), Eurocode 8: Design of structures for earthquake resistance - Part 1: General rules, seismic actions and rules for buildings, EN 1998-1. (2004).

[29] European Committee for Standardization (CEN), Eurocode 3: Design of Steel Structures - Part 1-1: General Rules and Rules for Buildings, EN 1993-1-1. (2005).

[30] A. Zona, A. Dall'Asta, Elastoplastic model for steel buckling-restrained braces, J. Constr. Steel Res. 68 (2012) 118-125. https://doi.org/10.1016/j.jcsr.2011.07.017.

[31] American Society of Civil Engineers, Seismic Evaluation and Retrofit of Existing Buildings, ASCE/SEI 41-17. (2017). https://doi.org/10.1061/9780784414859. 